International Business and Global Economy 2018, no. 37, pp. 183-197

Biznes międzynarodowy w gospodarce globalnej 2018, nr 37, s. 183-197

Edited by the Institute of International Business, University of Gdańsk

ISSN 2300-6102

e-ISSN 2353-9496

DOI 10.4467/23539496IB.18.013.9386

Sylwia Talar

Uniwersytet Ekonomiczny w Katowicach

\title{
Narzędzia polityki handlowej w obszarze e-commerce
}

Głównym celem artykułu jest specyfikacja narzędzi polityki handlowej w obszarze handlu elektronicznego. $\mathrm{W}$ analizie uwzględniono działania i regulacje właściwe dla tradycyjnej polityki handlowej oraz nowe bariery związane $\mathrm{z}$ technologią wykorzystywaną w transgranicznym handlu elektronicznym (CBEC). Dodatkowym celem jest zilustrowanie działań koordynacyjnych podejmowanych przez rządy państw na forum międzynarodowym i wkładu organizacji międzynarodowych $\mathrm{w}$ harmonizację regulacji dotyczących CBEC. W badaniu zastosowano metodę przeglądu literatury z baz: Scopus, Ebsco, ProQest i Web of Knowledge. Prześledzono działania głównych organizacji międzynarodowych oraz przeanalizowano akty prawne i inne dokumenty oficjalne. Dokonano syntezy wszystkich informacji i wyników badań oraz przedstawiono liczne wnioski szczegółowe. Ogólna teza mówi, iż stworzenie systemu zasad sprzyjającego długotrwałemu rozwojowi CBEC wymaga jeszcze wielu wysiłków, badań i jest bardzo skomplikowane, gdyż oznacza nie tylko wprowadzenie zasad wolnego handlu w tradycyjnym rozumieniu, ale równocześnie zapewnienie otwartego i bezpiecznego korzystania z technologii informacyjno-komunikacyjnych.

Słowa kluczowe: transgraniczny e-commerce, polityka handlowa, bariery handlu, międzynarodowe organizacje gospodarcze, regulacje Internetu

Klasyfikacja JEL: F13, F42, O38

\section{Trade policy measures in e-commerce}

The main aim of the paper is to identify trade policy measures and barriers in e-commerce. The analysis took account of the actions and regulations typical of traditional trade policy and new barriers related to the technology on which cross-border e-commerce (CBEC) is based. The additional objective is to illustrate the coordination activities undertaken by governments at the international level and the contribution of international organizations to the harmonization of CBEC regulations. The study reviews literature form the Scopus, Ebsco, ProQest, and Web of Knowledge databases. The actions of international organizations were studied and legislative acts and other documents issued by them were analysed. All information and research results were synthesized and numerous detailed findings provided. The overall conclusion is that still much has to be done to establish a system of rules conducive to long-standing CBEC growth, which requires much further research and is very complicated as it requires not only introducing free trade rules in traditional meaning but also providing open and safe use of ICT.

Keywords: cross-border e-commerce, trade policy, trade barriers, international economic organizations, Internet regulations

JEL classification: F13, F42, O38 


\section{Wprowadzenie}

Handel międzynarodowy, tak jak inne obszary gospodarki, podlega intensywnym zmianom wywołanym rewolucją cyfrową i upowszechnieniem ICT. Obserwujemy nie tylko rosnące wykorzystanie komunikacji elektronicznej w międzynarodowych transakcjach handlowych, ale przede wszystkim powstawanie nowych form i modeli wymiany, które wcześniej w środowisku międzynarodowym nie występowały lub nie były rozpowszechnione. Takim nowym zjawiskiem jest transgraniczny handel elektroniczny (cross-border e-commerce-CBEC). Jego dynamiczny rozwój stanowi obecnie jedną z najważniejszych cech gospodarki światowej. Prognozy wskazują, że CBEC skierowany do konsumentów indywidualnych nadal będzie wzrastał w szybkim tempie ze średnioroczną stopą wzrostu (CAGR) wynoszącą w latach 2015-2020 około 25\% i w 2020 r. osiągnie wartość sprzedaży na poziomie 1 bln USD, stanowiąc blisko 30\% globalnego e-commerce [Manyika, 2016; DHL, 2016]. Zainteresowanie tą formą wymiany wykazują przedsiębiorcy, którzy widzą w niej perspektywy szybkiej i efektywnej ekspansji zagranicznej, konsumenci poszukujący wygody oraz taniej, bogatej i łatwo dostępnej oferty, a także rządy państw z uwagi na konsekwencje, jakie niesie dla tradycyjnego handlu międzynarodowego i całej gospodarki oraz społeczeństwa. Tym samym CBEC staje się ważnym obszarem oddziaływania państwa, polegającego na wprowadzaniu regulacji i zasad determinujących jego funkcjonowanie.

Wyzwania, jakie niesie CBEC, i potrzeby regulacyjne, z jakimi się wiąże, nie zawsze jednak spotykają się z zainteresowaniem ze strony środowiska zajmującego się handlem międzynarodowym. Pokazują to m.in. konferencje, które odbyły się w USA w 2014 r. pod wspólnym tytułem „Wyzwania światowego systemu handlu” („,Challenges Facing the World Trade System”) z udziałem wybitnych przedstawicieli świata nauki i polityki. W publikacji będącej ich efektem i wydanej pod redakcją światowych autorytetów w tej dziedzinie [Bhagwati, Krishana, Panagariya, 2016] wskazuje się, że stanowi ona najnowszą analizę istotnych trendów $\mathrm{w}$ światowym systemie handlowym, ale jednocześnie problematyka CBEC jest w niej nieobecna. Wydaje się, że głosy wyraźnie mówiące o potrzebach międzynarodowych regulacji CBEC [Bieron, Ahmed, 2012] nie są dobrze słyszalne. Może to też wskazywać na całkowicie rozdzielne traktowanie handlu międzynarodowego i CBEC.

Istnieje zatem silna potrzeba podjęcia badań rodzącego się systemu zasad CBEC i określenia jego miejsca w globalnym układzie handlu. W związku z tym powstaje również pytanie o charakter, narzędzia i metody koordynacji polityki prowadzonej wobec CBEC. Jest to jednak zagadnienie bardzo szerokie. Jego zakres wynika z włączenia jeszcze do tradycyjnego światowego systemu handlowego 
obszarów pośrednio dotyczących handlu międzynarodowego (trade-related measures) oraz złożonej i wieloaspektowej natury samego CBEC. Ta specyfika CBEC jest konsekwencją połączenia globalnych co do istoty technologii internetowych z fizycznym światem i jego barierami, w którym te technologie są wykorzystywane. Ponadto CBEC nie zastąpił handlu tradycyjnego, ale z nim wspólistnieje i w pewnym sensie konkuruje. Jego rozwój determinują zatem zarówno tradycyjne czynniki wpływające na handel międzynarodowy, jak i nowe, związane z wykorzystywaną technologią. Ten ostatni aspekt jest szczególnie istotny, gdyż stanowiąc podstawę CBEC, powinien zostać włączony w obszar polityki handlowej, nadając jej nowy wymiar.

Głównym celem podjętego badania jest specyfikacja narzędzi polityki handlowej $\mathrm{w}$ obszarze handlu elektronicznego (e-commerce - EC). Uwzględniono działania i regulacje właściwe dla tradycyjnej polityki handlowej, takie jak cła, podatki pośrednie, kontrola państwa, ochrona własności intelektualnej, a także nowe bariery związane $\mathrm{z}$ wykorzystywaną w CBEC technologią, tj. ochronę konsumenta, danych i prywatności, bariery techniczne i piractwo domenowe. Biorąc pod uwagę fakt, że zagadnienia dotyczące polityki handlowej obejmują nie tylko stosowane instrumenty, ale też międzynarodową jej koordynację [Smith, 2013], dodatkowym celem artykułu jest zilustrowanie takich działań podejmowanych na forum międzynarodowym i wkładu organizacji globalnych w harmonizację regulacji dotyczących CBEC.

$\mathrm{W}$ badaniu zastosowano metodę przeglądu literatury z baz: Scopus, Ebsco, ProQest i Web of Knowledge. Prześledzono działania głównych organizacji międzynarodowych oraz przeanalizowano wydawane przez nie dokumenty i akty prawne. Dokonano syntezy wszystkich informacji i przedstawiono wnioski wskazujące na rodzaj i charakter stosowanych narzędzi polityki handlowej w obszarze EC, stopień jej międzynarodowej koordynacji oraz problemy, jakie w tej sferze występują.

Przedmiotem niniejszego badania jest CBEC $\mathrm{w}$ wąskim znaczeniu, rozumiany jako transakcje sprzedaży towarów fizycznych zawierane online (poprzez sieci komputerowe) z zagranicznymi konsumentami (B2C). Szeroką definicję EC prezentuje OECD [2017, s. 5], zaliczając do nich także transakcje, których przedmiotem są usługi i informacje, $\mathrm{w}$ tym dostarczane elektronicznie, i które mogą być zawierane z innymi przedsiębiorstwami (B2B) lub instytucjami rządowymi (B2G). Przyjęty zakres analizy wynika ze znacznego zróżnicowania poszczególnych form EC i dodatkowych problemów spowodowanych ich umiędzynarodowieniem. Kompleksowe ujęcie pociągałoby za sobą konieczność przeprowadzenia znacznie szerszego badania. 


\section{Polityka celna}

Kwestie celne $\mathrm{w}$ tradycyjnym handlu międzynarodowym od dawna są wyraźną domeną WTO oraz World Customs Organization (WCO). WTO rozpoczęła prace nad CBEC w 1998 r., przyjmując deklarację zakładającą powołanie specjalnego programu roboczego do badania handlowych aspektów globalnego EC. Wówczas na forum tej organizacji potwierdzono wolę powstrzymania się od nakładania ceł na „elektroniczną transmisję”, nie przesądzając jednak o końcowych wynikach działalności tego programu [WTO, 1998]. Po prawie dwudziestu latach, na konferencji ministerialnej w Buenos Aires w grudniu 2017 r., podjęto taką samą decyzję [WTO, 2017b], wyznaczając czas jej obowiązywania do kolejnej sesji w 2019 r.

Z kolei WCO w zrewidowanej Konwencji z Kioto (Revised Kyoto Convention), która weszła w życie 3 lutego 2006 r., przyjęła możliwość stosowania systemu zwolnień podatkowo-celnych dla przesyłek o małej wartości poprzez wyznaczanie minimalnych poziomów wartości lub sumy należności z tytułu ceł i podatków, poniżej których nie będą one pobierane [WCO, 2008, art. 4.13; WCO, 2014]. WCO nie określa przy tym wysokości tych progów ani nie narzuca minimalnych standardów, pozostawiając te kwestie regulacjom narodowym. Ponadto w szerszy i bardziej szczegółowy sposób zajmuje się tymi problemami, wskazując, że transakcje CBEC ze względu na swój charakter są wrażliwe na czas dostawy, wiążą się one z dużą liczbą małych przesyłek, realizowane są z udziałem nieznanych graczy, a przy tym należy uwzględnić proces zwrotu towaru i refundacji [WCO, 2018]. To z kolei pociąga za sobą konieczność zapewnienia odpowiedniej szybkości i efektywności procedur celnych przy rosnącym wolumenie takich transakcji i ryzyku wynikającym z ograniczonej wiedzy na temat importerów, oraz odpowiedniej jakości danych, identyfikacji nadużyć, prawidłowości klasyfikacji i stosowania reguł pochodzenia towarów czy integracji EC z tradycyjnym handlem.

Biorąc pod uwagę powyższe, WCO deklaruje wspieranie rozwoju CBEC poprzez stworzenie w ścisłej kooperacji z rządami, organizacjami międzynarodowymi i sektorem prywatnym zharmonizowanego podejścia i wprowadzenia wspólnych standardów oraz zasad ułatwiających i zwiększających bezpieczeństwo tego typu transakcji, a także dokładniejsze i efektywniejsze metody poboru ceł i podatków [WCO, 2017a], oraz planuje w lipcu 2018 r. przedstawić kompleksowe zharmonizowane międzynarodowe standardy dla CBEC („Framework of Standards on Cross-Border E-Commerce").

Abstrahując od oceny możliwości realizacji tych zamierzeń, należy podkreślić, iż aktualna polityka celna wobec CBEC, prowadzona przez znaczną część państw, polega na stosowaniu zwolnień celnych dla przesyłek o małej wartości, co stanowi pewien element harmonizacji wynikający też z deklaracji WTO. 
Jednak minimalne progi i dodatkowe przepisy są bardzo zróżnicowane, np. w Szwajcarii taki próg wynosi około 5 USD, w Australii około 800 USD, a w Chinach nie ma tego typu ograniczeń, lecz istnieją inne regulacje określające łączną wartość przesyłek na osobę [WCO, 2017b]. Tak więc, mimo zróżnicowania polityki celnej obowiązującej na poszczególnych rynkach, CBEC B2C korzysta obecnie w znacznym stopniu z preferencji celnych w porównaniu z tradycyjnym handlem międzynarodowym.

Dotychczasowe niewielkie zaangażowanie WTO w proces kształtowania zasad CBEC może jednak wzrosnąć, gdyż w oświadczeniu z grudnia 2017 r. [WTO, 2017a] znajduje się informacja o przygotowaniach do podjęcia przez nią w przyszłości negocjacji dotyczących handlowych aspektów e-commerce. Możliwości WTO w tym zakresie nie są jednak oczywiste, gdyż, jak wskazuje Mishra [2017], WTO nie jest odpowiednia do zajmowania się złożonymi problemami CBEC i w związku z odmiennym podejściem poszczególnych państw do zarządzania Internetem i kształtowania warunków jego wykorzystania do działań mających stworzyć system zasad przyjaznych rozwojowi CBEC należy włączyć także organizacje pozarządowe, takie jak: ICANN, ITU, Internet Society (ISOC) czy Międzynarodowa Sieć Ochrony Konsumentów (ICPEN).

\section{Podatki pośrednie}

Podatki pośrednie, takie jak VAT i podatek od sprzedaży, choć stanowią odrębną kwestię istotnie wpływającą na CBEC, też w pewnym stopniu wiążą się z cłami. Nie były one dotychczas przedmiotem szczegółowych uzgodnień w ramach negocjacji handlowych na forum WTO, mimo że w handlu online mogą powodować istotne zniekształcenia. Główny problem stanowi efektywne zastosowanie przy opodatkowaniu towarów w CBEC B2C zasady kraju przeznaczenia, powszechnie przyjętej w handlu międzynarodowym B2B. Opiera się ona na skutecznej kontroli przepływu produktów przez granice celne lub, tak jak w UE, oraz na ścisłym obowiązku ewidencyjnym i wspólnym systemie identyfikacji podatkowej. W przypadku CBEC B2C nie jest to obecnie możliwe do zastosowania. Alternatywne podejście do opodatkowania $\mathrm{w}$ handlu międzynarodowym, oparte na zasadzie kraju pochodzenia, wiąże się z kolei z innymi negatywnymi konsekwencjami, takimi jak:

- nierówne traktowanie na rynku towarów zagranicznych i krajowych wynikające z różnych stawek podatkowych, którym by podlegały (naruszenie zasady klauzuli narodowej - KN),

- zniekształcenie handlu w wyniku transferu towarów przez kraje o najniższych stawkach podatkowych, 
- konkurencja podatkowa,

- potrzeba redystrybucji wpływów podatkowych pobranych w kraju pochodzenia do kraju sprzedaży (przeznaczenia), jako że istotą tego typu podatków jest ponoszenie ich ciężaru przez ostatecznego nabywcę.

Trudności $w$ praktycznym zastosowaniu do CBEC modeli podatkowych wykorzystywanych dotychczas $\mathrm{w}$ handlu zagranicznym spowodowały powszechne przyjęcie takiego samego jak przy cłach systemu zwolnień podatkowych dla transakcji o niskich wartościach, chociaż są też przypadki odmiennych uregulowań. Stosowanie takich preferencji na szeroką skalę stanowi swego rodzaju precedens i oznacza preferowanie zagranicznych sprzedawców online w stosunku do krajowych, jak też preferowanie CBEC wobec tradycyjnego handlu offline, obciążonego wszystkimi podatkami. Paradoksalnie zatem to towary i podmioty krajowe są dyskryminowane wobec zagranicznych. Przyjęcie systemu zwolnień podatkowo-celnych jest w pewnym sensie wymuszone, gdyż koszt poboru podatków w tego rodzaju obrocie byłby wyższy od uzyskanych wpływów. Jednak dynamicznie rozwijający się CBEC i rosnący w związku z tym wolumen transakcji o niskiej wartości przyniósł też dotkliwe uszczuplenie wpływów budżetowych państw, w wyniku czego wskazuje się jednak potrzebę zmiany tego systemu.

Efektem działań koordynacyjnych na szczeblu międzynarodowym w tym obszarze jest opracowanie przez OECD [2015] pierwszych od stu lat zaleceń istotnych zmian w międzynarodowym systemie podatków. Zaprezentowano w sumie cztery modele poboru należności podatkowych, w odniesieniu do CBEC wskazano jednak, że efektywny i skuteczny pobór i przepływ podatków w imporcie jest uwarunkowany uzyskaniem przez administrację celno-podatkową odpowiednich informacji na temat tych transakcji.

Badacze problemów podatkowych w CBEC [Chen, Smekal, 2009] wskazują na potrzebę włączenia tych kwestii do negocjacji handlowych pod auspicjami WTO ze względu na naruszanie przez nie zasady niedyskryminacji handlu. Równocześnie proponują oni zastosowanie zasady kraju przeznaczenia przy założeniu udzielania dodatkowego wsparcia eksportera w postaci przekazywania przez niego odpowiednich informacji. Zarówno w tych propozycjach, jak i w modelu OECD dostęp do szczegółowych informacji jest warunkiem efektywnego opodatkowania transakcji CBEC. Tymczasem problem gromadzenia i dostępu do takich danych nie został dotychczas rozwiązany [Talar, 2017] i nawet pewne działania podjęte na forum międzynarodowym $w$ tej sferze nie uwzględniają informacji o jednorazowych indywidualnych transakcjach. To stawia pod znakiem zapytania możliwość przyjęcia proponowanych rozwiązań. Na potrzebę prowadzenia badań służących stworzeniu efektywnego systemu opodatkowania transakcji online zwracają też uwagę Agrawal i Fox [2016] i zachęcają do wyciągania wniosków 
z doświadczeń innych państw, a w szczególności UE. Dążenie do zmian systemu zwolnień podatkowych potwierdzają działania UE, która podjęła już decyzję o zniesieniu od 2021 r. zwolnień VAT dla małych przesyłek w CBEC [Council of the EU, 2017].

\section{Kontrola państwa}

Tak jak w tradycyjnym handlu międzynarodowym, tak też w CBEC, niezależnie od wykorzystania w nim globalnej technologii, państwo może podejmować działania mające na celu bezpośrednie kontrolowanie działalności podmiotów poprzez wydawanie przepisów zakazujących, nakazujących lub stawiających warunki dopuszczenia produktów i podmiotów na dany rynek. W badaniach barier tego typu [National Board of Trade, 2011] zidentyfikowano dwa ich rodzaje:

- zakaz wykorzystania kanału e-commerce w sprzedaży niektórych produktów,

- wymóg fizycznej obecności (zarejestrowania działalności) w celu prowadzenia sprzedaży online.

W pierwszym z powyższych przypadków podmioty CBEC są dyskryminowane przede wszystkim w stosunku do tradycyjnych firm. Biorąc jednak pod uwagę fakt, że firmy krajowe mają większe w porównaniu z zagranicznymi podmiotami możliwości sprzedaży produktów innymi kanałami i częściej prowadzą działalność w modelu sprzedaży wielokanałowej (clik and mortar), to pomimo iż dotyczy ich taki sam zakaz, w rzeczywistości często są w korzystniejszej sytuacji. Takie regulacje stanowią w istocie embargo dla podmiotów działających w czystej formie CBEC (pure players) na danym rynku. Dotychczas narzędzia tego typu były rzadko stosowane i dotyczyły produktów, które mogą być niebezpieczne dla konsumentów lub którymi obrót wiąże się z dużym prawdopodobieństwem oszustw i działalności przestępczej (np. farmaceutyki, niektóre gry online).

Drugi rodzaj wymienionych powyżej barier, tj. dotyczący fizycznej obecności podmiotu na rynku sprzedaży, stanowi podważenie istoty CBEC jako właśnie sprzedaży transgranicznej. Dyskryminuje ona pure players w stosunku do clik and mortar i handlu tradycyjnego (brick and mortar). Wymogi obecności fizycznej i rejestracji wynikają z obaw państw wobec firm zagranicznych sprzedających tylko online produkty na rynku krajowym i stanowią próbę zabezpieczenia interesów nabywców. Ocena ich zasadności pozostaje kwestią otwartą, ale ich negatywny wpływ na CBEC jest oczywisty.

Bariery tego typu mogą też przybierać łagodniejsze formy, jak np. wymóg zarejestrowania działalności dla możliwości zarejestrowania nazwy w krajowej domenie najwyższego rzędu (dla Polski jest to .pl), co nie jest niezbędne dla sprzedaży online na danym rynku, ale jej posiadanie jest często kluczowe dla prowa- 
dzenia CBEC (np. ze względu na zasady działania wyszukiwarek) i jej brak stawia firmy zagraniczne w niekorzystnej pozycji konkurencyjnej [National Board of Trade, 2011].

\section{Ochrona praw własności intelektualnej}

Bariery wynikające z ochrony praw własności intelektualnej dotyczą w największym stopniu handlu usługami i produktami cyfrowymi, jak: filmy, muzyka, aplikacje itp. Zostaną one w niniejszej analizie zasygnalizowane, gdyż tworzą największą lub jedną z największych barier ze względu na to, iż kwestie ochrony własności intelektualnej są regulowane w przeważającej mierze przepisami narodowymi ukierunkowanymi na ochronę narodowych interesów i brakuje harmonizacji międzynarodowej $w$ tym obszarze [National Board of Trade, 2012]. Problem ten występuje także $w$ handlu tradycyjnym, ale w warunkach środowiska cyfrowego bez barier geograficznych nabrał większego znaczenia i jest szczególnie dotkliwy dla firm CBEC sprzedających równocześnie na wielu różnych rynkach bez fizycznej na nich obecności.

Do najważniejszych ograniczeń należy zaliczyć brak jasnych regulacji i informacji, jak legalnie korzystaći obracać produktami chronionymi, a w szczególności jak dotrzeć do informacji, czy dany produkt jest objęty taką ochroną w sytuacji, gdy prawa autorskie nie muszą być nigdzie zarejestrowane ani ich posiadacz nie musi należeć do stowarzyszenia lub innej organizacji zajmującej się zbiorowym zarządzaniem takimi prawami lub może przekazać je osobie trzeciej. Sama trudność w znalezieniu właściwych informacji generuje wysokie koszty transakcyjne. Istniejące uregulowania nie eliminują zatem niepewności prawnej, która rodząc ryzyko naruszenia praw własności, powoduje, że firmy chcące działać bezpiecznie wycofują się lub powstrzymują (w tym blokują) świadczenie usług za granicą w obawie o naruszenie tych praw. Ponadto, nawet jeśli firmy dysponują właściwą informacją, to narodowe organizacje i związki reprezentujące posiadaczy praw udzielają najczęściej licencji ograniczonych co do geograficznego obszaru ich wykorzystania (tylko na poszczególne kraje), co poważnie utrudnia prowadzenie działalności transgranicznej. Brak harmonizacji w tej sferze występuje także w samej UE, mimo ustanowienia jednolitego rynku wewnętrznego, chociaż podjęte w ostatnich latach działania mają tę sytuację zmienić [UE, 2014; 2016b].

W skali globalnej proponowane jest utworzenie centralnej bazy łączącej narodowe rejestry ze wszystkich krajów. Nie dotarto jednak do źródeł, które wskazywałyby na udział Światowej Organizacji Własności Intelektualnej (WIPO) $\mathrm{w}$ globalnym pokonaniu wskazanych $\mathrm{w}$ tym punkcie barier. Złożoność niniejszych problemów wymaga zdecydowanie szerszej analizy i oceny, co nie mieści się $\mathrm{w}$ ramach niniejszego opracowania. 


\section{Ochrona konsumenta}

Polityka ochrony konsumenta w handlu międzynarodowym to nowy obszar regulacji skierowany konkretnie do CBEC B2C. Głównym celem wprowadzenia przepisów chroniących prawa konsumenta (np. prawo do odstąpienia od umowy, gwarancja, rozstrzyganie sporów) w handlu transgranicznym jest zbudowanie jego zaufania do tego typu transakcji, co powinno sprzyjać rozwojowi CBEC. Oznacza to, że brak takich regulacji stanowiłby barierę dla CBEC. Działania koordynacyjne w tej sferze podjęto na forum międzynarodowym już w 1999 r., kiedy OECD przyjęło pierwszy międzynarodowy instrument służący ochronie konsumentów w EC [OECD, 1999]. Nowa, zmodyfikowana i rozszerzona wersja wytycznych dla polityki państw została opublikowana w 2016 r. [OECD, 2016]. Działania w tym obszarze równolegle prowadzi także UNCTAD [2017], wskazując, że w sferze ochrony praw konsumenta online stopień adopcji prawa w poszczególnych państwach jest niższy niż w odniesieniu do przepisów chroniących prywatność, dane i przeciwdziałających cyberprzestępczości. Mimo międzynarodowych wytycznych konkretne uregulowania na poszczególnych rynkach mogą się jednak różnić (w UE obowiązuje tzw. dyrektywa konsumencka) i firmy nie są zwolnione $\mathrm{z}$ obowiązku analizowania krajowych przepisów. Zniechęca to do wchodzenia zwłaszcza na małe rynki, dla których koszty pozyskania będą większe od potencjalnych zysków. Jest to problem szczególnie dotkliwy dla małych firm, które posiadają ograniczone zasoby.

Badania nad rozwiązaniem problemu ochrony konsumentów w CBEC przeprowadzone przez Yuthayotin [2014] wykazały jednak, że harmonizacja prawa nie rozwiązałaby tego problemu. Zamiast tego autor proponuje włączenie się samego państwa w EC w roli pośrednika, co pozwoliłoby też zmniejszyć zakres regulacji. Istotnym założeniem $\mathrm{w}$ tej koncepcji jest zapewnienie przez państwo dostępu do wymiaru sprawiedliwości i transparentności. Abstrahując od oceny tego rozwiązania, należy zauważyć, że jego zastosowanie mogłoby rozwiązać też inne problemy, np. zbieranie informacji o transakcjach w celach statystycznych i podatkowo-celnych.

\section{Ochrona danych i prywatności}

Tradycyjne powiązanie działalności handlowej z przepływem informacji $\mathrm{w}$ warunkach gospodarki cyfrowej zrodziło nowe, bardzo poważne i złożone problemy. Dane towarzyszą międzynarodowym transakcjom handlowym i w związku z ich zawieraniem są gromadzone oraz przetwarzane. Dzięki cyfrowej technice istotnie wzrosło ich znaczenie i obecnie dane mogą służyć jako:

- waluta, którą „płaci się” za tzw. darmowe produkty,

- cenny surowiec, na bazie którego można kreować nowe produkty, 
- uniwersalny materiał, który można wykorzystać do praktycznie każdego celu,

- towar, który można po prostu sprzedać.

Handel danymi już należy traktować jako nowy rodzaj obrotu gospodarczego [Manyika i in., 2016].

Dodatkowym aspektem, w kontekście którego należy rozpatrywać dane, jest ochrona prywatności, gdyż często wśród nich znajdują się też dane osobowe. Problem ten dotyka zarówno firm, jak i całych gospodarek. Ma też konsekwencje dla sprawy o fundamentalnym znaczeniu dla obywateli i państw - ochrony podstawowych praw człowieka i bezpieczeństwa narodowego. Ochrona danych stanowi też podstawę zaufania do Internetu jako narzędzia i determinuje stopień jego wykorzystania. Ogromna skala problemu uzgodnienia zasad i regulacji w tym zakresie wynika z konieczności znalezienia rozwiązania, które w idealnej postaci zapewniałoby jednocześnie swobodę przepływu danych, umożliwiającą realizację interesów ekonomicznych, oraz ochronę interesów konsumentów i państw. Obecnie wydaje się to niemożliwe do osiągnięcia. Z kolei rozwiązanie second-best, sprowadzające się do wyznaczenia "rozsądnego" balansu między interesami ekonomicznymi a interesami konsumentów i państw, wywołuje wiele kontrowersji, gdyż dotychczas kwestie o fundamentalnym znaczeniu nie były przedmiotem oficjalnego „targowania się". Biorąc pod uwagę ciągły i szybki rozwój technologiczny, w tym zwłaszcza Big Data, a także ujawnione przez Edwarda Snowdena działania rządu USA w postaci programu PRISM [Greenwald, MacAskill, 2013], nasuwa się pytanie o cenę bezpieczeństwa jako podstawowej wartości i możliwości jej wymiany za określone korzyści ekonomiczne.

W odpowiedzi na zagrożenia związane z międzynarodowym przepływem danych państwa wprowadzają regulacje zakazujące transferu danych osobowych (i ewentualnie innego ich rodzaju) poza granice kraju. Obowiązek lokalizacji danych w kraju ich pochodzenia oznacza też konieczność fizycznego umiejscowienia tam pewnej części działań (serwerów) związanych z prowadzoną na tym rynku działalnością. Uregulowania w tej sferze są różne w poszczególnych państwach w zależności od podejścia do praw podstawowych, ale też interesów ekonomicznych i hierarchii wartości. UE podchodzi do ochrony danych i prywatności kompleksowo i restrykcyjnie, gwarantując wysoki jej stopień [UE, 1995; 2016a]. Z kolei USA, posiadając uprzywilejowaną pozycję wynikającą z dominacji amerykańskich firm internetowych na rynku światowym (Google, Facebook, Apple, Amazon i wiele innych), są orędownikiem swobody przepływu danych i uznają obowiązek lokalizacji danych za barierę w handlu, generującą poważne straty ekonomiczne dla UE i innych państw stosujących takie rozwiązania [ECIPE, 2013]. Wśród argumentów przeciwko wprowadzaniu takich ograniczeń wskazuje się też negatywny ich wpływ na rozwój technologii [Chander, Le, 2014] i sugeruje, że być może przyszłe układy handlowe będą zawierać sankcje za nakładanie obowiązku lokalizacji danych [ECIPE, 2014]. 
Kierując się wyraźnym własnym interesem, USA podejmują działania, by kwestie swobody przepływu danych włączyć do umów handlowych negocjowanych w stosunkach bilateralnych i regionalnych (np. umowa z Koreą, TTIP, TPP), oraz zawierają w tym celu inne układy. Przykładem jest porozumienie „Safe Harbour" zawarte z UE, które po wyroku Trybunału Sprawiedliwości UE z 6 października 2015 r. w sprawie C-362/14 Schrems - Facebook zostało unieważnione i zastąpione kolejnym porozumieniem „Privacy Shield” (Commission Implementing Decision (EU) 2016/1250 of 12 July 2016 pursuant to Directive 95/46/EC). Kontrowersyjność porozumień obejmujących transfer danych także dobrze ilustrują negocjacje Umowy w sprawie handlu usługami (TISA) [Aaronson, 2015]. Poważny konflikt między różnymi interesami związanymi z przepływem danych wskazuje, że zawieranie międzynarodowych umów handlowych służących interesom ekonomicznym bez wcześniejszego odpowiedniego zabezpieczenia podstawowych praw na tym samym szczeblu i jasnego wyznaczenia hierarchii priorytetów oraz zasad wykorzystania technologii stanowi niewłaściwą kolejność działań. Zmiana tego podejścia oznaczałaby podjęcie działań na forum takich organizacji, jak ONZ, Human Rights Watch czy Amnesty International. Przyjęcie nowych regulacji wydaje się jednak niezbędne, gdyż dotychczasowe Międzynarodowe Pakty Praw Człowieka i nawet działania organu kontrolnego Międzynarodowego Paktu Praw Obywatelskich (Osobistych) i Politycznych w postaci Komisji Praw Człowieka nie są wystarczające, głównie ze względu na niewiążący dla państw-stron charakter wydawanych decyzji.

Z punktu widzenia CBEC, dla którego istotny pozostaje nie tylko przepływ danych i informacji, ale też zaufanie do wykorzystywanej technologii, podstawowe znaczenie miałoby przejrzyste uregulowanie tych kwestii na forum globalnym. Analiza przeprowadzona przez UNCTAD [2016] potwierdza jednak, że przepisy są zróżnicowane, a w niektórych państwach kwestie te w ogóle nie są regulowane i w konsekwencji brakuje jednego modelu ochrony danych. Główne tezy opracowania UNCTAD są w swej istocie potwierdzeniem, z jednej strony, bardzo dużego i rosnącego znaczenia ochrony danych i prywatności w środowisku online, a z drugiej - braku harmonizacji w tej sferze i potrzeby osiągnięcia większej kompatybilności przepisów.

\section{Bariery techniczne dla handlu i piractwo domenowe}

Jedną z form bezpośredniego oddziaływania na wykorzystanie nowych technologii, a przez to w sposób pośredni na CBEC, jest cenzura Internetu, która najczęściej przyjmuje formę blokowania stron i stanowi nową formę protekcjonizmu na rynku elektronicznym. Zjawisko to, chociaż najczęściej kojarzone z takimi kra- 
jami jak Chiny, może przybierać różną formę, wynikać z różnych przyczyn i być stosowne przez różne podmioty i na różnym szczeblu [Erixon, Hindley, Lee-Makiyama, 2009]. Cenzura zazwyczaj służyła celom politycznym, ale w dobie agresywnej konkurencji i gospodarki cyfrowej zdominowanej przez efekty sieciowe stała się też narzędziem wykorzystywanym do celów ekonomicznych. Stosowana w oficjalny sposób przez Chiny jest przedmiotem międzynarodowej krytyki. Zaskakuje jednak fakt, że pomimo ostrego sprzeciwu wobec takich działań ze strony wielu państw, a zwłaszcza USA, nie wszczęto oficjalnych procedur zmierzających do jej zakazania. Wyjaśnieniem tego zjawiska może być niechęć ze strony krajów rozwiniętych do stworzenia precedensu zakazu wprowadzania restrykcji w dostępie do Internetu -instrumentu, który być może same będą chciały wykorzystać dla bezpieczeństwa narodowego [Deese, 2014, s. 579].

Inną specyficzną dla CBEC barierą są przestępcze działania, powszechnie nazywane piractwem domenowym (cybersquatting). Polegają one generalnie na rejestrowaniu nazw domen podobnych do nazw istniejących marek handlowych i wykorzystywaniu ich w złej wierze, czyli np. w celu blokowania do nich dostępu, oferowania ich sprzedaży za wysoką cenę lub wprowadzania w błąd użytkowników Internetu [Lindsay, 2007, s. 96]. Co istotne, brakuje wielostronnych regulacji, które bezpośrednio określałyby zasady rejestracji takich samych lub podobnych nazw domen w innych krajach. W tej sytuacji pozostaje tylko możliwość rozstrzygania powstałych na tym tle sporów $\mathrm{w}$ odpowiednich sądach arbitrażowych (krajowych dla domen krajowych i międzynarodowych dla domen funkcjonalnych). Pozytywnym aspektem jest to, że zasady rozstrzygania sporów dotyczących domen internetowych zastały już ujednolicone (Rules for Uniform Domain Name Dispute Resolution Policy - UDRP) w 1999 r. przez ICANN w porozumieniu z WIPO, co w znacznym stopniu ułatwia dochodzenia praw przez firmy, których podstawę działalności stanowi nazwa domeny.

\section{Podsumowanie}

Powstanie, a w szczególności dynamiczny rozwój nowej formy handlu międzynarodowego, jaką jest CBEC, przyniósł szereg wyzwań dla rządów państw i organizacji międzynarodowych tworzących światowy system gospodarczy. Handel towarami fizycznymi na rynku elektronicznym stanowi syntezę rynku tradycyjnego i nowego rynku elektronicznego, który podobnie jak ten pierwszy nie jest rynkiem doskonałym i wymaga regulacji. $Z$ tego wynika złożony charakter samego EC, a jego umiędzynarodowienie (CBEC) rozszerza problem optymalizacji warunków dla wymiany międzynarodowej i koordynacji działań w ramach prowadzonej polityki na nowe obszary. 
Na podstawie badania poszczególnych narzędzi polityki handlowej i barier wpływających na CBEC można stwierdzić, że:

- nowe technologie nie wyeliminowały barier w handlu międzynarodowym, ale przyniosły nowe ich rodzaje, rozszerzając zakres narzędzi pośrednio związanych z handlem;

- narzędzia polityki wobec CBEC można podzielić na tradycyjne narzędzia polityki handlowej (cła, podatki, kontrola państwa, ochrona własności intelektualnej) oraz nowe narzędzia, właściwe dla EC (ochrona konsumenta, ochrona danych i prywatności, bariery techniczne i piractwo domenowe);

- narzędzia szeroko rozumianej polityki handlowej mogą sprzyjać, utrudniać lub nawet eliminować CBEC;

- niektóre tradycyjne narzędzia polityki handlowej, takie jak cła i podatki, stawiają obecnie CBEC w pozycji uprzywilejowanej w stosunku do handlu tradycyjnego;

- regulacje w większości obszarów związanych z CBEC są niestabilne i podlegają ciągłym zmianom, co może być jednak specyficznym uwarunkowaniem tego handlu wynikającym z ciągłego rozwoju technologii, na której się on opiera;

- nie udało się dotąd stworzyć światowego systemu transgranicznego handlu elektronicznego;

- główną formą międzynarodowej koordynacji polityki handlowej w obszarze CBEC jest opracowywanie przez międzynarodowe organizacje wytycznych dla regulacji tworzonych przez państwa, co skutkuje podobnymi, aczkolwiek zróżnicowanymi, przepisami w poszczególnych krajach;

- udział WTO w tworzeniu systemu zasad sprzyjających CBEC jest bardzo mały, a działania są rozproszone na wiele różnych organizacji, przez co brakuje całościowego podejścia do uregulowania warunków rozwoju CBEC;

- istnieją wątpliwości, czy WTO jest w stanie zająć się złożonymi problemami CBEC;

- barierę dla CBEC stanowią zarówno zróżnicowane regulacje i wymagania, jak i całkowity brak regulacji, który tworzy niepewność i obniża zaufanie do samej technologii;

- istnieje wiele kontrowersji co do zakresu i sposobu regulacji w obszarze CBEC, skutków stosowanych narzędzi, a także priorytetów polityki handlowej;

- badacze problemu podają w wątpliwość możliwość wyeliminowania barier związanych z technologicznymi aspektami CBEC poprzez harmonizację przepisów i proponują niekonwencjonalne rozwiązania, których możliwości zastosowania i potencjalne skutki nie są jeszcze dobrze poznane.

Rozpoczęty w drugiej połowie lat dziewięćdziesiątych XX w. proces tworzenia systemu zasad dla nowo powstałej elektronicznej formy handlu międzynarodowego jest nadal kontynuowany. $\mathrm{W}$ miejsce harmonizacji wybrano formę 
międzynarodowej koordynacji przepisów regulujących wykorzystanie globalnej technologii, co z istoty prowadzi do tworzenia barier i budowania granic tam, gdzie ich nie było. Ocena tego rozwiązania pozostaje jednak otwarta, zważywszy na fakt, że technologia ta charakteryzuje się bardzo szeroką funkcjonalnością i nie jest jedynie narzędziem zawierania transakcji handlowych czy dystrybucji produktów. Stworzenie sprzyjających warunków dla długotrwałego rozwoju CBEC oznacza nie tylko wprowadzenie zasad wolnego handlu w tradycyjnym rozumieniu, ale równocześnie zapewnienie otwartego i stabilnego (bezpiecznego) Internetu. Waga technicznych aspektów we współczesnym prawie i polityce jest ogromna, co powinno skłaniać do zintensyfikowania badań w tym obszarze.

\section{Bibliografia}

Aaronson S., 2015, Why Trade Agreements are not Setting Information Free. The Lost History and Reinvigorated Debate over Cross-Border Data Flows, Human Rights and National Security, World Trade Review, April.

Agrawal D.R., Fox W.F., 2016, Taxes in an E-Commerce Generation, CESifo Working Paper Series, no. 6050.

Bhagwati J.N., Krishana P., Panagariya A (eds.), 2016, The World Trade System. Trends and Challenges, MIT Press.

Bieron B., Ahmed U., 2012, Regulating E-commerce through International Policy. Understanding the International Trade Law Issues of E-commerce, Journal of World Trade, vol. 46, issue 3.

Chander A., Le U.P., 2014, Breaking the Web. Data Localization vs. the Global Internet, Working Paper 2014-1, California International Law Center.

Chen J., Smekal C., 2009, Should the WTO deal with e-trade taxation issues?, Progress in Development Studies, vol. 9, issue 4.

Council of the EU, 2017, VAT w e-handlu. Nowe przepisy, komunikat prasowy 734/17, 5.12.2017.

Deese D. (ed.), 2014, Handbook of the International Political Economy of Trade, Edward Elgar.

DHL, 2016, The 21st Century Spice Trade a Guide to The Cross-Border E-Commerce Opportunity. A Guide to the Cross-Border E-Commerce Opportunity.

ECIPE, 2013, The Economic Importance of Getting Data Protection Right. Protecting Privacy, Transmitting Data, Moving Commerce, European Centre for International Political Economy for the U.S. Chamber of Commerce, Brussels.

ECIPE, 2014, The Costs of Data Localisation. Friendly Fire on Economic Recovery.

Erixon F., Hindley B., Lee-Makiyama H., 2009, Protectionism Online. Internet Censorship and International Trade Law, ECIPE Working Paper, no. 12.

Greenwald G., MacAskill E., 2013, NSA Prism program taps in to user data of Apple, Google and others, The Guardian, 7 June.

Lindsay D., 2007, International Domain Name Law. ICANN and the UDRP, Hart Publishing.

Manyika J., Lund S., Bughin J., Woetzel J., Stamenov K., Dhingra D., 2016, Digital globalization. The new era of global flows, McKinsey, Global Institute.

Mishra N., 2017, International trade, Internet governance and the shaping of the digital economy, ARTNeT Working Paper Series, no. 168. 
National Board of Trade, 2011, Survey of e-commerce barriers within the EU, Kommerskollegium Sweden.

National Board of Trade, 2012, E-commerce - New Opportunities, New Barriers A survey of e-commerce barriers in countries outside the EU, Kommerskollegium Sweden.

OECD, 1999, Guidelines for Consumer Protection in the Context of Electronic Commerce.

OECD, 2015, Addressing the Tax Challenges of the Digital Economy, Action 1-2015 Final Report.

OECD, 2016, Consumer Protection in E-commerce. OECD Recommendation.

OECD, 2017, Measuring digital trade. Towards a conceptual framework.

Smith P.J., 2013, Global Trade Policy. Questions and Answers, Wiley-Blackwell.

Talar S., 2017, Cross-border e-commerce - problemy identyfikacji i pomiaru, Współczesna Gospodarka, vol. 8, issue 3 .

UE, 1995, Directive 95/46/EC of the European Parliament and of the Council of 24 October 1995 on the protection of individuals with regard to the processing of personal data and on the free movement of such data.

UE, 2014, Dyrektywa Parlamentu Europejskiego i Rady 2014/26/UE z dnia 26 lutego 2014 r. w sprawie zbiorowego zarządzania prawami autorskimi i prawami pokrewnymi oraz udzielania licencji wieloterytorialnych dotyczących praw do utworów muzycznych do korzystania online na rynku wewnętrznym, Dz. Urz. UE L 84 z 20 marca 2014 r.

UE, 2016a, Regulation (EU) 2016/679 of the European Parliament and of the Council of 27 April 2016 on the protection of natural persons with regard to the processing of personal data and on the free movement of such data, and repealing Directive 95/46/EC (General Data Protection Regulation) (Text with EEA relevance).

UE, 2016b, Wniosek Dyrektywa Parlamentu Europejskiego i Rady w sprawie praw autorskich na jednolitym rynku cyfrowym, COM/2016/0593 final - 2016/0280 (COD).

UNCTAD, 2016, Data protection regulations and international data flows. Implications for trade and development.

UNCTAD, 2017, Consumer protection in electronic commerce. Note by the UNCTAD secretariat.

WCO, 2008, The International Convention on the Simplification and Harmonization of Customs Procedures (as amended), http://www.wcoomd.org/Topics/Facilitation/Instrument $\% 20$ and\%20Tools/Conventions/pf_revised_kyoto_conv/Kyoto_New [dostęp: 12.01.2018].

WCO, 2014, Guidelines for the Immediate Release of Consignments by Customs.

WCO, 2017a, Resolution of The Policy Commission of The World Customs Organization on The Guiding Principles for Cross-Border E-Commerce, Luxor, December.

WCO, 2017b, WCO Study Report on Cross-Border E-Commerce, March.

WCO, 2018, Cross-border E-commerce, http://www.wcoomd.org/Topics/Facilitation/ Activities $\%$ 20and\%20Programmes/Ecommerce [dostęp: 12.01.2018].

WTO, 1998, Declaration on global electronic commerce, WT/MIN(98)/DEC/2.

WTO, 2017a, Joint statement on Electronic Commerce, WT/MIN(17)/60, 13 December.

WTO, 2017b, Ministerial Decision of 13 December 2017, Work Programme On Electronic Commerce, WT/MIN(17)/65, WT/L/1032, 18 December.

Yuthayotin S., 2014, Access to Justice in Transnational B2C E-Commerce. A Multidimensional Analysis of Consumer Protection Mechanisms, Springer.

S. Talar (®) sylwia.talar@ue.katowice.pl

Wydział Ekonomii, Uniwersytet Ekonomiczny w Katowicach, ul. 1 Maja 50,

40-287 Katowice, Polska 